\title{
Malaria prevalence in Nias District, North Sumatra Province, Indonesia
}

\author{
Din Syafruddin*1,2, Puji BS Asih ${ }^{1}$, Isra Wahid², Rita M Dewi ${ }^{3}$, Sekar Tuti \\ Idaman Laowo ${ }^{4}$, Waozidohu Hulu ${ }^{4}$, Pardamean Zendrato ${ }^{4}$, \\ Ferdinand Laihad ${ }^{5}$ and Anuraj H Shankar ${ }^{6}$
}

\begin{abstract}
Address: ${ }^{1}$ Eijkman Institute for Molecular Biology, Jalan Diponegoro 69, Jakarta 10430, Indonesia, ${ }^{2}$ Department of Parasitology, Faculty of Medicine, Hasanuddin University, Makassar, Indonesia, ${ }^{3}$ National Institute of Health Research and Development The Ministry of Health, Jakarta, Indonesia, ${ }^{4}$ Nias District Health Department, North Sumatra Province, Indonesia, ${ }^{5}$ Malaria Sub-directorate, Vector Borne Diseases Directorate, Directorate General for Communicable Diseases Control and Environmental Sanitation, the Ministry of Health, Jakarta, Indonesia and ${ }^{6}$ World Health Organization, Jakarta, Indonesia

Email: Din Syafruddin* - din@eijkman.go.id; Puji BS Asih - puji@eijkman.go.id; Isra Wahid - iwahid@yahoo.com;

Rita M Dewi - marleta@litbang.depkes.go.id; Sekar Tuti - sekartuti@litbang.depkes.go.id; Idaman Laowo - idamanlaowo@yahoo.com; Waozidohu Hulu -waozidohuhulu@yahoo.com; Pardamean Zendrato - pardameanzendrato@yahoo.com; Ferdinand Laihad - laihad@centrin.net.id; Anuraj H Shankar - ShankarA@who.or.id

* Corresponding author
\end{abstract}

Published: 30 August 2007

Malaria Journal 2007, 6:116

doi: $10.1|86 /| 475-2875-6-1 \mid 16$
Received: I April 2007

Accepted: 30 August 2007

This article is available from: http://www.malariajournal.com/content/6/1/116

(c) 2007 Syafruddin et al; licensee BioMed Central Ltd.

This is an Open Access article distributed under the terms of the Creative Commons Attribution License (http://creativecommons.org/licenses/by/2.0), which permits unrestricted use, distribution, and reproduction in any medium, provided the original work is properly cited.

\begin{abstract}
Background: The Nias district of the North Sumatra Province of Indonesia has long been known to be endemic for malaria. Following the economic crisis at the end of 1998 and the subsequent tsunami and earthquake, in December 2004 and March 2005, respectively, the malaria control programme in the area deteriorated. The present study aims to provide baseline data for the establishment of a suitable malaria control programme in the area and to analyse the frequency distribution of drug resistance alleles associated with resistance to chloroquine and sulphadoxinepyrimethamine.
\end{abstract}

Methods: Malariometric and entomology surveys were performed in three subdistricts. Thin and thick blood smears were stained with Giemsa and examined under binocular light microscopy. Blood blots on filter paper were also prepared for isolation of parasite and host DNA to be used for molecular analysis of band 3 (SAO), pfcrt, pfmdrl, dhfr, and dhps. In addition, haemoglobin measurement was performed in the second and third surveys for the subjects less than 10 years old.

Results: Results of the three surveys revealed an average slide positivity rate of $8.13 \%$, with a relatively higher rate in certain foci. Host genetic analysis, to identify the Band 3 deletion associated with Southeast Asian Ovalocytosis (SAO), revealed an overall frequency of $1.0 \%$ among the I,484 samples examined. One hundred six Plasmodium falciparum isolates from three sub-districts were successfully analysed. Alleles of the $\mathrm{dhfr}$ and $\mathrm{dhps}$ genes associated with resistance to sulphadoxinepyrimethamine, dhfr C59R and SI08N, and dhps A437G and K540E, were present at frequencies of $52.2 \%, 82.5 \%, 1.18 \%$ and $1.18 \%$, respectively. The pfmdrl alleles N86Y and NI042D, putatively associated with mefloquine resistance, were present at $31.4 \%$ and $2 \%$, respectively. All but one sample carried the pfcrt 76T allele associated with chloroquine resistance. Entomologic surveys 
identified three potential anopheline vectors in the area, Anopheles barbirostris, Anopheles kochi and Anopheles sundaicus.

Conclusion: The cross sectional surveys in three different sub-districts of Nias District clearly demonstrated the presence of relatively stable endemic foci of malaria in Nias District, North Sumatra Province, Indonesia. Molecular analysis of the malaria parasite isolates collected from this area strongly indicates resistance to chloroquine and a growing threat of resistance to sulphadoxine-pyrimethamine. This situation highlights the need to develop sustainable malaria control measures through regular surveillance and proper antimalarial drug deployment.

\section{Background}

The Nias archipelago has been known to be endemic for malaria long before the natural disasters that hit the area in December 2004 and March 2005 [1,2], and to be a focus of drug resistant malaria. Both in vivo and in vitro chloroquine in Nias were described as early as 1981 [3]. Nias district was among the first locations in Indonesia where cases of chloroquine resistance in Plasmodium vivax were found $[4,5]$. Treatment failures associated with the use of sulphadoxine-pyrimethamine have also been reported in falciparum malaria cases [2]. Studies associated with the mosquito vectors revealed several anopheline mosquitoes in Nias, including Anopheles sundaicus, Anopheles sinensis, Anopheles tessellates, Anopheles crawfordi and Anopheles kochi $[2,6,7]$, but only the first three species have been confirmed to transmit malaria. The recent monetary crisis and natural disasters have led to a deterioration of the malaria control programme in the area, culminating in the persistence of a relatively stable endemic focus and outbreak of malaria in many places after the tsunami [8].

The tsunami and the earthquake have badly affected areas along the north and west coast of the Nias archipelago. Many primary health centers and their supporting facilities were damaged. In addition, some health professionals were either killed or displaced during the two natural disasters, impairing disease control efforts in the area. In relation to malaria surveillance specifically, no primary health center in Nias District currently has any adequately trained microscopists. The present study is an effort to provide baseline data for the establishment of an appropriate malaria control programme in the area, by reviving the malaria surveillance programme in the tsunami-areas in Nanggroe Aceh Darussalam (NAD) Province and Nias District of the North Sumatra Province, using conventional and molecular tools. Results of three cross sectional malariometric surveys, host genetic analysis and entomologic surveys in Nias District, North Sumatra Province Indonesia are presented here.

\section{Methods \\ Description of study site}

Nias archipelago is located off the western coast of the island of Sumatra, between $0.5^{\circ}-1.5^{\circ}$ North latitude and $96^{\circ} 59^{\prime}-97^{\circ} 58^{\prime}$ East longitude, and comprises one main island and several smaller islands (Figure 1). The administration of the islands is divided into two districts, Nias and South Nias districts. Nias district is further divided into 14 sub-districts. The Nias archipelago occupies an area of $5,625 \mathrm{~km}^{2}$ with a total population of approximately 641,832 in Nias district alone. Rainfall is very high, with over three meters annually and 270 rainy days per year. The relative humidity is about $90 \%$ all year round with average temperature between $14-31^{\circ} \mathrm{C}$ from January to June and $22-30^{\circ} \mathrm{C}$ from July to December. The rainy season is from October to January, whereas the drier season starts from February to July. The main occupation of the inhabitants is farming.

\section{Malariometric survey}

Malariometric surveillance was performed in three selected sub-districts, Lahewa, Sirombu and Mandrehe. This activity involved active and passive detection of malaria cases, using thick and thin blood smears, rapid diagnostic tests using immunochromatography test (ICT), and molecular detection using polymerase chain reaction (PCR) amplification of parasite DNA isolated from filter paper blood spots prepared from finger-pricks. For field surveys, selection of the village was based on the previous available information on malaria endemicity. All of the village inhabitants were invited to undergo parasitologic screening for malaria by submitting a drop of blood for blood smears and blot. The blood samples were considered positive if either the blood smear or the PCR was positive. Because PCR is demonstrably more sensitive than microscopy, a positive finding by PCR being consistent with a negative finding microscopy was regarded positive. During such surveys, basic 7-day morbidity history, including axial temperature and spleen grading, was recorded along with nutritional status and haemoglobin levels using a portable digital haemocytometer (Haemocue Hb201+, Angelholm, Sweden). In all cases, persons who were parasite positive were given appropriate drug treatment. This study received ethical clearance for 

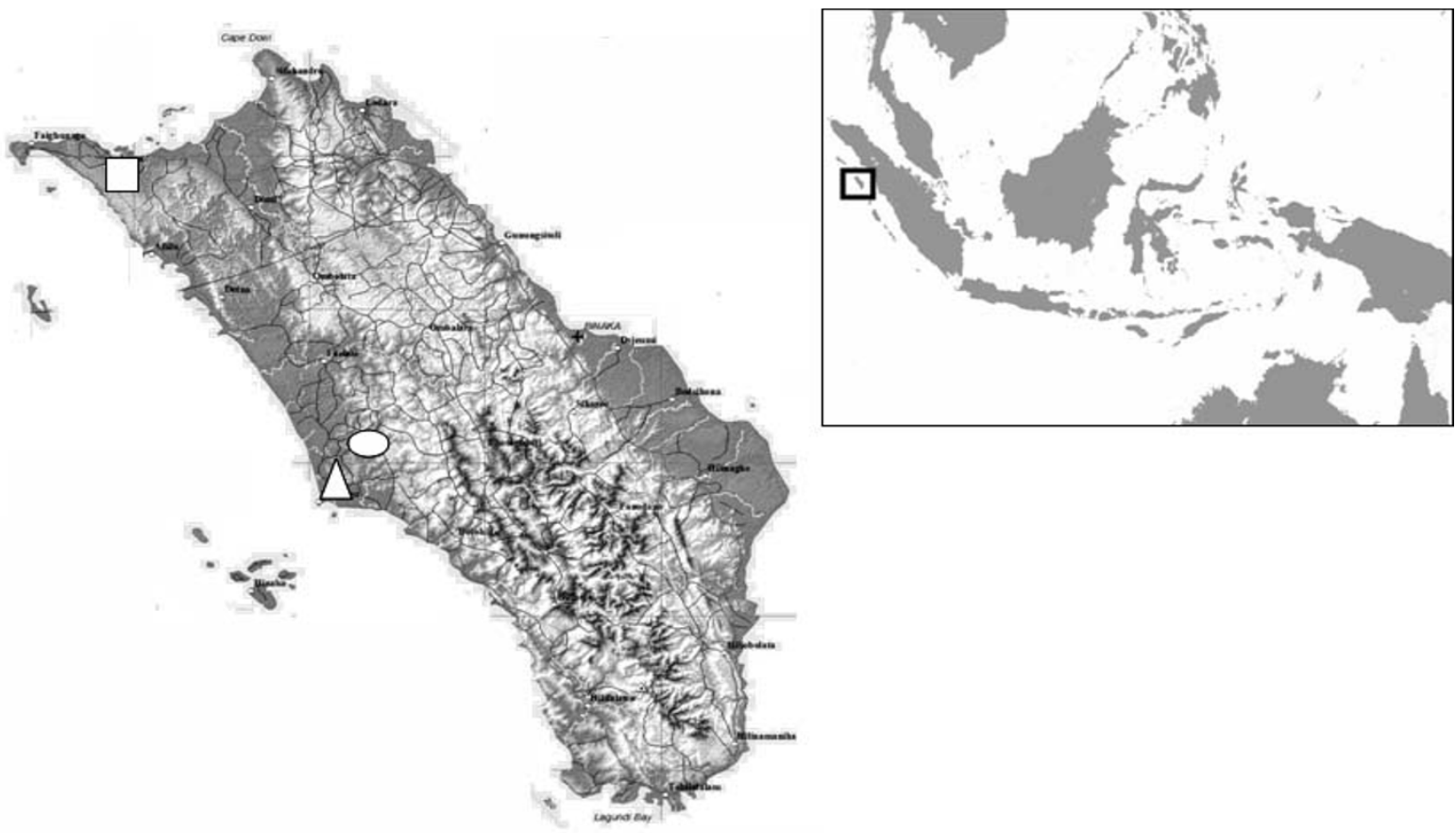

Figure I

A sketch map of Nias District and its geographic location within North Sumatra Province, Republic Indonesia. The location of three selected sub-districts; Lahewa (triangle), Sirombu (square), and Mandrehe (circle) are shown.

the use of human subject from the Eijkman Institute Research Ethics Committee, Jakarta, Indonesia

\section{Entomologic survey}

Collection of mosquito larvae and adults was carried out from households and adjacent areas. Adult mosquitoes were collected using light traps, capture on landing sites and human bait in- and outdoors using aspirator. Larva and/or pupae were collected in various habitats. For each habitat sampled, a collection record describing water temperature, conductivity, salinity and $\mathrm{pH}$ was made. Aquatic stages were transported to a laboratory and individually reared to the adult stage to determine the species using the illustrated keys of Indonesian anophelines. In addition, humidity, rainfall and average temperature were measured.

\section{Extraction of DNA}

Parasite and human host DNA was extracted from the blood samples using chelex-100 ion exchanger (Biorad Laboratories, Hercules, CA), according to the procedure described previously [9]. The DNA was either used immediately for PCR or stored at $-20^{\circ} \mathrm{C}$ for later analysis.

\section{Molecular analyses on the parasite and host}

Molecular analyses were performed using PCR amplification and restriction fragment length polymorphism (RFLP) on several genes of the parasite, including $d h f r$, dhps, pfmdr1, pfcrt and of the host genes such as a band-3 gene deletion, indicative of Southeast Asian Ovalocytosis (SAO). The PCR reactions were carried out as previously described [10].

\section{Results \\ Malariometric survey}

The malaria prevalence in each sub-district during the three cross sectional surveys in October 2005, December 2005 and February 2006 respectively is shown in Table 1. Two species of malaria parasites, Plasmodium falciparum and $P$. vivax were found, mostly as single infections except in one case in Sirombu village. PCR analysis of all samples positive by microscopy and 10\% randomly-chosen slidenegative samples revealed no discordance between the diagnosis by microscopy and PCR. The overall slide positivity rates were $9.9 \%, 6.4 \%$ and $8.1 \%$ in October 2005 , December 2005 and February 2006, respectively. The vast majority of the malaria positive cases were in children less 
Table I: Malaria Prevalence in Lahewa, Sirombu and Mandrehe Sub-districts, Nias Districts, North Sumatra Province, Indonesia

\begin{tabular}{|c|c|c|c|c|c|c|c|c|c|c|c|c|c|}
\hline \multirow[t]{3}{*}{ Sub-districts } & \multirow[t]{3}{*}{ Village } & \multicolumn{12}{|c|}{ Malaria Cases } \\
\hline & & \multicolumn{4}{|c|}{ October 2005} & \multicolumn{4}{|c|}{ December 2005} & \multicolumn{4}{|c|}{ February 2006} \\
\hline & & Pf & Pv & $\underset{(\mathbf{P f}+\mathbf{P v})}{\operatorname{Mix}}$ & $\begin{array}{l}\text { Number } \\
\text { Of Slides }\end{array}$ & Pf & Pv & $\operatorname{mix}_{(\mathbf{P f}+\mathbf{P v})}^{\operatorname{Mix}}$ & $\begin{array}{l}\text { Number } \\
\text { Of Slides }\end{array}$ & Pf & $\mathbf{P v}$ & $\begin{array}{c}\operatorname{Mix}_{(\mathbf{P f}+\mathbf{P v})} \\
\end{array}$ & $\begin{array}{l}\text { Number } \\
\text { Of Slides }\end{array}$ \\
\hline & Lahewa & $9(5.7)$ & (0) & (0) & 158 & $9(6.6)$ & I (0.7) & (0) & 136 & $\mathrm{I}(\mathrm{I} . \mathrm{I})$ & (0) & (0) & 91 \\
\hline \multirow[t]{2}{*}{ LAHEWA } & Marfala & $8(12.7)$ & (0) & (0) & 63 & $11(30.5)$ & (0) & (0) & 36 & $5(8.3)$ & (0) & (0) & 60 \\
\hline & Balafadorotuho & $10(10.3)$ & $3(3.1)$ & (0) & 97 & (0) & (0) & (0) & 78 & $5(7)$ & $5(7)$ & (0) & 71 \\
\hline SIROMBU & Sirombu & $7(6.7)$ & (0) & (0) & 104 & $9(5.5)$ & $I(0.6)$ & (0) & 162 & $10(6.3)$ & $3(1.9)$ & $I(0.6)$ & 159 \\
\hline \multirow{2}{*}{ MANDREHE } & OnolimbuRaya & $6(7)$ & (0) & (0) & 86 & (0) & (0) & (0) & 44 & $2(5.5)$ & I (2.8) & (0) & 36 \\
\hline & Sisarahili & $9(25)$ & $2(5.5)$ & (0) & 36 & (0) & (0) & (0) & 30 & $3(8.1)$ & I (2.7) & (0) & 37 \\
\hline $\begin{array}{l}\text { Total } \\
\text { individuals } \\
\text { examined }\end{array}$ & & $49(9)$ & $5(0.9)$ & (0) & 544 & $29(6)$ & $\begin{array}{c}2 \\
(0.4)\end{array}$ & (0) & 486 & $\begin{array}{c}26 \\
(5.7)\end{array}$ & $\begin{array}{c}10 \\
(2.2)\end{array}$ & $\mathrm{I}(0.2)$ & 454 \\
\hline
\end{tabular}

* Number in bracket indicates percentage, Pf: Plasmodium falciparum, Pv: Plasmodium vivax,

than 10 years old (Table 2). At the village level, the highest malaria prevalence was found in Marfala village in the Lahewa sub-district with a $30.5 \%$ slide positivity rate during the survey in December 2005. This prevalence decreased to $8.3 \%$ in February. In the Mandrehe sub-district, the highest prevalence was detected in the Sisarahili village with $25 \%$ slide positivity rate during the survey of October 2005.

\section{Haemoglobin measurement}

The haemoglobin $(\mathrm{Hb})$ level was also measured in the 448 children of less than 10 years of age sampled during the second and third surveys. The relationship between $\mathrm{Hb}$ status and malaria infection is shown in Table 3. Among the 448 samples examined, 75 (16.7\%) had moderate anaemia and three $(0.67 \%)$ children had severe anaemia. Of the 75 cases that had mild and severe anaemia, six $(8 \%)$ cases were found to have falciparum malaria.

\section{Southeast Asian Ovalocytosis}

The frequency distribution of SAO, a genetic disorder of red blood cells that is associated with malaria morbidity, was also checked among the samples examined. The results indicated that the overall frequency of this genetic disorder in the three selected sub-district was $1.0 \%$ (Table 4 ). However, at the village level, most of the cases were from the Lahewa and Sirombu villages respectively.

\section{Entomologic survey}

Entomologic surveys to identify the potential mosquito vector in the surveyed area identified two anopheline species, An. barbirostris and An. kochi in Sirombu village of Sirombu sub-district. These two species were captured using light trap installed outside of houses in the village. The larval stage of both species was also found in grassy ground pools and grassy rice fields in the village. In Lahewa village, larvae of An. sundaicus and some other unidentified anopheline species were found in ground pools and concrete tanks, respectively. No adult anopheline mosquitoes were captured inside houses.

\section{Molecular assays of the P. falciparum isolates}

In total, 109 P. falciparum isolates were collected during three malariometric surveys in Nias District, Indonesia. Some samples failed to amplify using certain oligos, hence the gene polymorphism information obtained was incomplete, as described below.

Table 2: Prevalence of malaria infection in each age group in Lahewa, Sirombu and Mandrehe Sub-districts, Nias District, North Sumatra Province, Indonesia

\begin{tabular}{|c|c|c|c|c|c|c|c|c|c|}
\hline \multirow{2}{*}{$\begin{array}{c}\text { Age group } \\
\text { (from } \geq \text { to } \\
<\text { ) }\end{array}$} & \multicolumn{3}{|c|}{ October 2005} & \multicolumn{3}{|c|}{ December 2005} & \multicolumn{3}{|c|}{ February 2006} \\
\hline & $\operatorname{Pf}(\%)$ & $\operatorname{Pv}(\%)$ & $\begin{array}{c}\text { Mix Pf+Pv } \\
(\%)\end{array}$ & $\operatorname{Pf}(\%)$ & $\operatorname{Pv}(\%)$ & $\begin{array}{c}\text { Mix Pf+Pv } \\
(\%)\end{array}$ & Pf (\%) & $\operatorname{Pv}(\%)$ & $\begin{array}{c}\text { Mix Pf+Pv } \\
\text { (\%) }\end{array}$ \\
\hline $0-10$ & $44(8.1)$ & $5(0.9)$ & (0) & $29(6)$ & $2(0.4)$ & (0) & $23(5.1)$ & $9(1.9)$ & $\mathrm{I}(0.2)$ \\
\hline $10-20$ & $2(0.4)$ & $(0)$ & (0) & $(0)$ & (0) & (0) & I (0.2) & (0) & (0) \\
\hline $20-30$ & (0) & (0) & (0) & $(0)$ & (0) & (0) & $2(0.4)$ & $\mathrm{I}(0.2)$ & (0) \\
\hline $30-40$ & (0) & (0) & (0) & (0) & (0) & (0) & $(0)$ & $(0)$ & (0) \\
\hline $40-50$ & $3(0.5)$ & (0) & (0) & (0) & (0) & (0) & (0) & (0) & (0) \\
\hline
\end{tabular}


Table 3: Haemoglobin Status and Malaria Cases in Children, In Nias District, North Sumatra Province, Indonesia

\begin{tabular}{ccccc}
\hline Malaria infection & $\begin{array}{c}\text { No. } \\
\text { subjects }\end{array}$ & \multicolumn{3}{c}{ Hb (g \%) Status } \\
\cline { 3 - 5 } & & $<\mathbf{6}$ & $\mathbf{6 - 1 0}$ & $>10$ \\
\hline Uninfected & 412 & 2 & 68 & 342 \\
$P f$ & 26 & 1 & 5 & 20 \\
$P v$ & 9 & - & 2 & 7 \\
Mixed (Pf/Pv) & 1 & - & - & 1 \\
\hline Total & 448 & 3 & 75 & 370 \\
\hline
\end{tabular}

Genotypic profiles of P. falciparum isolates from Nias Polymorphisms in pfcrt and pfmdr I

Amplification of $p f c r t$ among the 106 P. falciparum DNA isolates from Nias District was successful in 101 isolates. RFLP analysis of the amplicons revealed that all carried the 76T allele in pfcrt, except one isolate collected from Marfala village, which carried the wild-type allele (Tables 5, 6 and 7). In $p f m d r 1$, among 102 isolates that rendered PCR products, 70 carried the wild-type allele and the remaining 32 isolates carried the $86 \mathrm{Y}$ polymorphism. The 1042D polymorphism was detected in two isolates, one each from Sirombu and Lahewa respectively. No polymorphisms at codons 1032 and 1246 of pfmdr1 were observed in any of the isolates examined.

Polymorphisms in dhfr and dhps

Amplification of $d h f r$ was successful with 69 isolates (Tables 5, 6 and 7). Of these, 52 isolates carried the $108 \mathrm{~N}$ polymorphism. No $108 \mathrm{~T}$ polymorphism was detected in any of the isolates examined. Analysis of codon 59 was successful in 69 isolates, and among these, two isolates were found to carry a mixture of both mutant and wildtype alleles. Thirty six isolates (51\%) were found to carry

Table 4: Frequency distribution of Southeast Asian Ovalocytocis in Lahewa, Sirombu and Mandrehe Sub-districts, Nias District, North Sumatra Province, Indonesia

\begin{tabular}{llcc}
\hline Sub-districts & Village & $\begin{array}{c}\text { SAO } \\
\text { (\%) }\end{array}$ & $\begin{array}{c}\text { Total } \\
\text { individuals } \\
\text { examined }\end{array}$ \\
\hline \multirow{3}{*}{ LAHEWA } & Lahewa & $9(2.3)$ & 385 \\
& Marfala & - & 159 \\
SIROMBU & Balefadorotuho & $\mathrm{I}(0.4)$ & 246 \\
& Sirombu & $5(1.2)$ & 425 \\
MANDREHE & Onolimbu Raya & - & 166 \\
& Sisarahili & - & 103 \\
Total & & $15(1)$ & 1484 \\
\hline
\end{tabular}

Table 5: Genotypic pattern of $P$. falciparum isolates from Nias District, North Sumatra Province, October 2005

\begin{tabular}{|c|c|c|c|c|c|c|c|c|c|}
\hline \multirow[t]{2}{*}{ No } & \multirow{2}{*}{$\begin{array}{c}\text { Sample } \\
\text { Code }\end{array}$} & \multicolumn{3}{|c|}{ DHFR } & \multicolumn{2}{|c|}{ DHPS } & \multicolumn{2}{|c|}{ Pfmdrl } & \multirow{2}{*}{$\begin{array}{l}\text { PfC } \\
R T \\
767\end{array}$} \\
\hline & & $16 \mathrm{~V}$ & $59 R$ & $\begin{array}{l}108 \\
N / T\end{array}$ & $\underset{G}{437}$ & $\begin{array}{c}540 \\
E\end{array}$ & $86 Y$ & $\underset{D}{1042}$ & \\
\hline $\mathrm{I}$. & $45 \mathrm{~L}$ & $A$ & - & $\mathrm{N}$ & G & $\mathrm{K}$ & $\mathrm{N}$ & $D$ & $\mathrm{~T}$ \\
\hline 2. & $52 \mathrm{~L}$ & - & - & - & A & $\mathrm{K}$ & $N$ & $\mathrm{~N}$ & $\mathrm{~T}$ \\
\hline 3. & $61 \mathrm{~L}$ & $A$ & $\mathrm{R}$ & $\mathrm{N}$ & $A$ & $\mathrm{~K}$ & $N$ & $\mathrm{~N}$ & $\mathrm{~T}$ \\
\hline 4. & $121 \mathrm{~L}$ & $A$ & C & $S$ & - & - & $\mathrm{N}$ & $\mathrm{N}$ & $\mathrm{T}$ \\
\hline 5. & $130 \mathrm{~L}$ & $A$ & - & $\mathrm{N}$ & - & - & $\mathrm{N}$ & $\mathrm{N}$ & $\mathrm{T}$ \\
\hline 6. & $143 \mathrm{~L}$ & $A$ & C & $S$ & - & - & $\mathrm{N}$ & $\mathrm{N}$ & $\mathrm{T}$ \\
\hline 7. & 147L & $A$ & - & $\mathrm{N}$ & $A$ & $\mathrm{~K}$ & $\mathrm{~N}$ & - & $\mathrm{T}$ \\
\hline 8. & IM & $A$ & C & $\mathrm{S}$ & - & - & $\mathrm{N}$ & $\mathrm{N}$ & $\mathrm{T}$ \\
\hline 9. & $6 M$ & - & - & - & A & $\mathrm{K}$ & $\mathrm{N}$ & $\mathrm{N}$ & $\mathrm{T}$ \\
\hline 10. & $27 M$ & $A$ & C & $\mathrm{N}$ & A & $\mathrm{K}$ & $Y$ & $\mathrm{~N}$ & $\mathrm{~T}$ \\
\hline II. & $37 M$ & $A$ & - & $\mathrm{N}$ & A & $\mathrm{K}$ & $Y$ & $\mathrm{~N}$ & $\mathrm{~T}$ \\
\hline 12. & $38 M$ & A & C & $S$ & $A$ & $\mathrm{~K}$ & $Y$ & - & $\mathrm{T}$ \\
\hline 13. & $44 M$ & $A$ & $\mathrm{R}$ & $\mathrm{N}$ & A & $\mathrm{K}$ & $Y$ & $\mathrm{~N}$ & $\mathrm{~T}$ \\
\hline 14. & $54 M$ & - & - & - & A & $\mathrm{K}$ & $\mathrm{N}$ & - & $\mathrm{T}$ \\
\hline 15. & $57 M$ & $A$ & C & $\mathrm{N}$ & A & $\mathrm{K}$ & $Y$ & $\mathrm{~N}$ & $\mathrm{~T}$ \\
\hline 16. & $40 \mathrm{BT}$ & $A$ & $\mathrm{R}$ & $\mathrm{N}$ & A & $\mathrm{K}$ & $\mathrm{N}$ & $\mathrm{N}$ & $\mathrm{T}$ \\
\hline 17. & $42 \mathrm{BT}$ & - & - & - & A & $\mathrm{K}$ & $N$ & $\mathrm{~N}$ & $\mathrm{~T}$ \\
\hline 18. & 44BT & - & $\mathrm{R}$ & - & A & $\mathrm{K}$ & $\mathrm{N}$ & $\mathrm{N}$ & $T$ \\
\hline 19. & $46 \mathrm{BT}$ & $A$ & - & $\mathrm{N}$ & A & $\mathrm{K}$ & $Y$ & $\mathrm{~N}$ & $T$ \\
\hline 20. & $48 \mathrm{BT}$ & - & $\mathrm{R}$ & - & $A$ & $\mathrm{~K}$ & $\mathrm{~N}$ & - & - \\
\hline 21. & $57 \mathrm{BT}$ & - & - & - & - & - & - & $\mathrm{N}$ & $\mathrm{T}$ \\
\hline 22. & 59BT & $A$ & $\mathrm{R}$ & $\mathrm{N}$ & $A$ & $\mathrm{~K}$ & $Y$ & $\mathrm{~N}$ & $T$ \\
\hline 23. & $84 \mathrm{BT}$ & $A$ & $\mathrm{R}$ & $\mathrm{N}$ & - & - & $Y$ & $\mathrm{~N}$ & $\mathrm{~T}$ \\
\hline 24. & $86 \mathrm{BT}$ & - & - & - & A & $\mathrm{K}$ & $Y$ & $\mathrm{~N}$ & $\mathrm{~T}$ \\
\hline 25. & $97 \mathrm{BT}$ & $A$ & $\mathrm{R}$ & $\mathrm{N}$ & A & $\mathrm{K}$ & $N$ & $\mathrm{~N}$ & $\mathrm{~T}$ \\
\hline 26. & $2 O R$ & - & - & - & A & $\mathrm{K}$ & $N$ & $\mathrm{~N}$ & $T$ \\
\hline 27. & 7OR & $A$ & $\mathrm{R}$ & $\mathrm{N}$ & A & $\mathrm{K}$ & $Y$ & $\mathrm{~N}$ & $\mathrm{~T}$ \\
\hline 28. & $8 O R$ & $A$ & C & $\mathrm{N}$ & A & $\mathrm{K}$ & $Y$ & $\mathrm{~N}$ & $\mathrm{~T}$ \\
\hline 29. & $120 R$ & $A$ & $\mathrm{R}$ & $\mathrm{N}$ & A & $\mathrm{K}$ & $Y$ & $\mathrm{~N}$ & $\mathrm{~T}$ \\
\hline 30. & $31 O R$ & $A$ & $\mathrm{R}$ & $\mathrm{N}$ & A & $\mathrm{K}$ & $N$ & $\mathrm{~N}$ & $\mathrm{~T}$ \\
\hline 31. & $32 \mathrm{OR}$ & - & - & - & A & $\mathrm{K}$ & $N$ & $\mathrm{~N}$ & $\mathrm{~T}$ \\
\hline 32. & $24 \mathrm{SH}$ & - & $\mathrm{R}$ & - & A & $\mathrm{K}$ & $Y$ & $\mathrm{~N}$ & $\mathrm{~T}$ \\
\hline 33. & $52 \mathrm{SH}$ & - & - & - & A & $\mathrm{K}$ & $Y$ & $\mathrm{~N}$ & $\mathrm{~T}$ \\
\hline 34. & $54 \mathrm{SH}$ & $A$ & C & $\mathrm{N}$ & A & $\mathrm{K}$ & $Y$ & $\mathrm{~N}$ & $T$ \\
\hline 35. & $55 \mathrm{SH}$ & $A$ & C & $\mathrm{N}$ & - & - & $Y$ & $\mathrm{~N}$ & $T$ \\
\hline 36. & $58 \mathrm{SH}$ & $A$ & C & $\mathrm{N}$ & A & $\mathrm{K}$ & - & $\mathrm{N}$ & $T$ \\
\hline 37. & $59 \mathrm{SH}$ & $A$ & $\mathrm{R}$ & $\mathrm{N}$ & A & $\mathrm{K}$ & $\mathrm{N}$ & $\mathrm{N}$ & $\mathrm{T}$ \\
\hline 38. & $64 \mathrm{SH}$ & - & $\mathrm{R}$ & - & A & $\mathrm{K}$ & $\mathrm{N}$ & $\mathrm{N}$ & $\mathrm{T}$ \\
\hline 39. & $72 \mathrm{SH}$ & $A$ & C & $\mathrm{N}$ & A & $\mathrm{K}$ & $N$ & $\mathrm{~N}$ & $\mathrm{~T}$ \\
\hline 40. & $78 \mathrm{SH}$ & $A$ & $\mathrm{R}$ & $\mathrm{N}$ & A & $\mathrm{K}$ & $\mathrm{N}$ & $\mathrm{N}$ & $\mathrm{T}$ \\
\hline 41. & $2 S R$ & - & - & - & $A$ & $\mathrm{~K}$ & $Y$ & $\mathrm{~N}$ & $\mathrm{~T}$ \\
\hline 42. & $3 S R$ & $A$ & $\mathrm{R}$ & $\mathrm{N}$ & - & - & - & $\mathrm{N}$ & $\mathrm{T}$ \\
\hline 43. & IISR & $A$ & - & $\mathrm{s}$ & A & $\mathrm{K}$ & $N$ & $\mathrm{~N}$ & - \\
\hline 44. & I8SR & $A$ & C & $\mathrm{N}$ & A & $\mathrm{K}$ & $\mathrm{N}$ & $\mathrm{N}$ & $\mathrm{T}$ \\
\hline 45. & 7OSR & $A$ & $\mathrm{R}$ & $\mathrm{N}$ & A & $\mathrm{K}$ & $N$ & $\mathrm{~N}$ & $\mathrm{~T}$ \\
\hline 46. & $8 I S R$ & $A$ & $\mathrm{R}$ & $\mathrm{N}$ & A & $\mathrm{K}$ & $Y$ & $\mathrm{~N}$ & - \\
\hline 47. & I03SR & $A$ & $\mathrm{R}$ & - & - & - & $Y$ & $\mathrm{~N}$ & - \\
\hline
\end{tabular}

the 59R mutant allele and the remainder the wild type 59C. No polymorphisms were observed at codons 16, 50, 51 , or 164 in any of the isolates examined. Amplification of $d h p s$ was successful in 85 isolates and among these one isolate carried the $437 \mathrm{G}$ allele and one carried the $540 \mathrm{E}$ allele, and the remainder were wildtype. No polymorphisms were observed at codons 436, 581 or 613 in any of the isolates examined in this study. 


\section{Discussion}

The strong earthquake and the tsunami that hit the northwestern coast of Sumatra and Nias in December 2004 damaged public health infrastructure in the area. This situation was worsened by the following earthquake in March 2005 in Nias, and most of the disease prevention and control measures were sidelined. Malaria was one of the major public health problems of the island long before the disasters hit the area and antimalarial drug resistance had long been documented [2,11]. Since September 2005, a bi-monthly surveillance to evaluate the post-tsunami malaria incidence in the tsunami affected areas of Nias was initiated. The results indicated a relatively stable malaria hypoendemic status in several villages of the three sub-districts Lahewa, Sirombu and Mandrehe, respectively. The findings are relatively similar to the results of previous surveys in several villages in the southern parts of the island in 1998, which are now part of the South Nias district [2]. The malaria prevalence tends to decrease in Lahewa village, which is located in the coastal area and functions as the primary town for the sub-district. This significant decrease of malaria incidence might be attributed to the intensely-conducted malaria treatment and insecticide spraying following the malaria outbreaks after the tsunami and the earthquake. However, in the other two inland villages, Marfala and Balefadorotuho, the prevalence of malaria seems to be relatively stable. There are several factors that may be associated with this situation; first, in the inland villages with a lowland forest setting, efforts to reduce the mosquito vector by insecticide spraying are difficult than on the coast, and second, malaria diagnosis and treatment may not be properly done or the parasite may have been resistant to the available antimalarial drugs. Indeed, previous surveys, have documented several falciparum and vivax malaria cases with chloroquine treatment failure $[2,11]$.

In support of the finding, the results of the molecular analysis also indicated that virtually all of the falciparum isolates examined carried the $p f c r t$ alleles associated with chloroquine resistance. With only a single exception, all of the $P$. falciparum isolates examined carried the pfcrt 76T mutant associated with chloroquine resistance. In addition, a high proportion of the isolates also carried the $86 \mathrm{Y}$ allele of the $p f m d r 1$ gene. The findings support the current policy to replace chloroquine with artemisinin-based combination therapy (ACT) as the first-line antimalarial treatment in the area.

Analysis of $d h f r$ indicated a high proportion of isolates carrying mutant alleles associated with resistance to pyrimethamine. However, the frequency of mutant alleles of $d h f r$ is slightly lower than that reported in a previous study done in the southern part of the island, but the difference is probably due to the larger sample size that was
Table 6: Genotypic pattern of $P$. falciparum isolates from Nias District, North Sumatra Province, December 2005

\begin{tabular}{|c|c|c|c|c|c|c|c|c|c|}
\hline \multirow[t]{2}{*}{ No } & \multirow{2}{*}{$\begin{array}{c}\text { Sample } \\
\text { Code }\end{array}$} & \multicolumn{3}{|c|}{ DHFR } & \multicolumn{2}{|c|}{ DHPS } & \multicolumn{2}{|c|}{ Pfmdrl } & \multirow{2}{*}{$\begin{array}{c}P f \\
C F \\
T \\
76 \\
T\end{array}$} \\
\hline & & $\begin{array}{l}16 \\
V\end{array}$ & $\begin{array}{c}59 \\
R\end{array}$ & $\begin{array}{l}10 \\
8 N \\
I T\end{array}$ & $\begin{array}{l}43 \\
7 G\end{array}$ & $\begin{array}{l}54 \\
O E\end{array}$ & $\begin{array}{c}86 \\
Y\end{array}$ & $\begin{array}{l}10 \\
42 \\
D\end{array}$ & \\
\hline I. & $2 S R-12$ & $A$ & $\mathrm{R}$ & $\mathrm{N}$ & $A$ & $\mathrm{~K}$ & $N$ & $D$ & $\mathrm{~T}$ \\
\hline 2. & $2 S R-13$ & - & - & - & $A$ & $\mathrm{~K}$ & $\mathrm{~N}$ & $\mathrm{~N}$ & $\mathrm{~T}$ \\
\hline 3. & $2 S R-28$ & - & - & S & $A$ & $\mathrm{~K}$ & $Y$ & $\mathrm{~N}$ & $\mathrm{~T}$ \\
\hline 4. & 2SR-3I & - & $\mathrm{R}$ & - & $A$ & $\mathrm{~K}$ & $N$ & $N$ & $\mathrm{~T}$ \\
\hline 5. & $2 S R-40$ & $A$ & $\mathrm{C}$ & $N$ & - & - & $N$ & $N$ & $\mathrm{~T}$ \\
\hline 6. & $2 S R-46$ & $A$ & C & $\mathrm{N}$ & $A$ & $\mathrm{~K}$ & $\mathrm{~N}$ & $\mathrm{~N}$ & $\mathrm{~T}$ \\
\hline 7. & $2 S R-49$ & - & C & - & $A$ & $\mathrm{~K}$ & $\mathrm{~N}$ & $\mathrm{~N}$ & $\mathrm{~T}$ \\
\hline 8. & 2SR-54 & - & - & - & - & - & $N$ & $N$ & $\mathrm{~T}$ \\
\hline 9. & 2SR-8I & - & - & - & $A$ & $\mathrm{~K}$ & $\mathrm{~N}$ & $\mathrm{~N}$ & $\mathrm{~T}$ \\
\hline 10. & $2 L W-5$ & $A$ & - & $N$ & $A$ & $\mathrm{~K}$ & $\mathrm{~N}$ & $\mathrm{~N}$ & $\mathrm{~T}$ \\
\hline 11. & $2 L W-17$ & - & - & - & $A$ & $\mathrm{~K}$ & $N$ & $N$ & $\mathrm{~T}$ \\
\hline 12. & $2 L W-45$ & - & - & - & - & - & $\mathrm{N}$ & $\mathrm{N}$ & $\mathrm{T}$ \\
\hline 13. & $2 L W-54$ & $A$ & C & $S$ & $A$ & $\mathrm{~K}$ & $\mathrm{~N}$ & $\mathrm{~N}$ & $\mathrm{~T}$ \\
\hline 14. & 2LW-77 & - & - & - & - & - & $\mathrm{N}$ & $\mathrm{N}$ & $\mathrm{T}$ \\
\hline 15. & $2 L W-84$ & $A$ & $\mathrm{R}$ & $\mathrm{N}$ & $A$ & $E$ & $\mathrm{~N}$ & $\mathrm{~N}$ & $\mathrm{~T}$ \\
\hline 16. & 2LW-85 & - & C & - & $A$ & $\mathrm{~K}$ & $N$ & $N$ & $\mathrm{~T}$ \\
\hline 17. & $2 L W-103$ & $A$ & $\mathrm{R}$ & $\mathrm{N}$ & $A$ & $\mathrm{~K}$ & $\mathrm{~N}$ & $\mathrm{~N}$ & $\mathrm{~T}$ \\
\hline 18. & $2 L W-107$ & $A$ & C & $\mathrm{N}$ & $A$ & $\mathrm{~K}$ & $Y$ & $\mathrm{~N}$ & $\mathrm{~T}$ \\
\hline 19. & $2 L W-114$ & $A$ & $\mathrm{C}$ & $\mathrm{N}$ & $A$ & $\mathrm{~K}$ & $Y$ & $\mathrm{~N}$ & $\mathrm{~T}$ \\
\hline 20. & 2M-I & $A$ & $C$ & $\mathrm{~S}$ & $A$ & $\mathrm{~K}$ & $\mathrm{~N}$ & $\mathrm{~N}$ & $\mathrm{~T}$ \\
\hline 21. & $2 M-5$ & $A$ & C & $S$ & - & - & $\mathrm{N}$ & $\mathrm{N}$ & $\mathrm{T}$ \\
\hline 22. & $2 M-7$ & $A$ & $\mathrm{C}$ & $N$ & A & $\mathrm{K}$ & $\mathrm{N}$ & $\mathrm{N}$ & $\mathrm{K}$ \\
\hline 23. & $2 M-8$ & - & $\mathrm{R}$ & - & $A$ & $\mathrm{~K}$ & $\mathrm{~N}$ & $\mathrm{~N}$ & $\mathrm{~T}$ \\
\hline 24. & $2 M-12$ & $A$ & C & $N$ & $A$ & $\mathrm{~K}$ & $\mathrm{~N}$ & $\mathrm{~N}$ & $\mathrm{~T}$ \\
\hline 25. & $2 M-17$ & $A$ & $\mathrm{C}$ & $\mathrm{N}$ & $A$ & $\mathrm{~K}$ & $\mathrm{~N}$ & $\mathrm{~N}$ & $\mathrm{~T}$ \\
\hline 26. & $2 M-20$ & - & - & - & $A$ & $\mathrm{~K}$ & $N$ & $N$ & $\mathrm{~T}$ \\
\hline 27. & $2 M-23$ & $A$ & $\mathrm{C}$ & $N$ & $A$ & $\mathrm{~K}$ & $\mathrm{~N}$ & $\mathrm{~N}$ & $\mathrm{~T}$ \\
\hline 28. & $2 M-24$ & - & - & - & - & - & $N$ & $\mathrm{~N}$ & $\mathrm{~T}$ \\
\hline 29. & $2 M-25$ & $A$ & $\mathrm{R}$ & $N$ & $A$ & $\mathrm{~K}$ & $\mathrm{~N}$ & $\mathrm{~N}$ & $\mathrm{~T}$ \\
\hline 30. & $2 M-26$ & - & $\mathrm{R}$ & - & $A$ & $\mathrm{~K}$ & $N$ & $\mathrm{~N}$ & $\mathrm{~T}$ \\
\hline 31. & $2 M-27$ & $A$ & $\mathrm{R}$ & $\mathrm{N}$ & $A$ & $\mathrm{~K}$ & $\mathrm{~N}$ & $\mathrm{~N}$ & $\mathrm{~T}$ \\
\hline 32. & $2 M-28$ & $A$ & $\mathrm{R}$ & $N$ & $A$ & $\mathrm{~K}$ & $\mathrm{~N}$ & $\mathrm{~N}$ & $\mathrm{~T}$ \\
\hline 33. & $2 M-36$ & - & - & - & $A$ & $\mathrm{~K}$ & $\mathrm{~N}$ & $N$ & $\mathrm{~T}$ \\
\hline
\end{tabular}

examined in this study. In the previous survey, the mutant alleles of $d h p s$ that associated with sulphadoxine were not found in any of the isolates examined. In this survey, two isolates that carry the $437 \mathrm{G}$ and $540 \mathrm{E}$ alleles respectively were detected. In other parts of Indonesia, mutations associated with resistance to sulphadoxine in the $d h p s$ gene are still relatively rare and the $437 \mathrm{G}$ polymorphism is the most common and earliest selected mutant allele of dhps [10]. In this regard, it is interesting to note that the $540 \mathrm{E}$ and $437 \mathrm{G}$ polymorphisms were not linked, as they have been suggested in previous reports $[10,12]$.

Analysis of the frequency distribution of SAO indicated that this genetic disorder is also present in Nias population, although its frequency is much lower than that of the 
Table 7: Genotypic pattern of $P$. falciparum isolates from Nias District, North Sumatra Province, February 2006

\begin{tabular}{|c|c|c|c|c|c|c|c|c|c|}
\hline \multirow[t]{2}{*}{ No } & \multirow{2}{*}{$\begin{array}{c}\text { Sample } \\
\text { Code }\end{array}$} & \multicolumn{3}{|c|}{ DHFR } & \multicolumn{2}{|c|}{ DHPS } & \multicolumn{2}{|c|}{ Pfmdrl } & \multirow{2}{*}{$\begin{array}{c}P f \\
C \\
R \\
T \\
76 \\
T\end{array}$} \\
\hline & & $\begin{array}{l}16 \\
V\end{array}$ & $59 R$ & $\begin{array}{l}10 \\
8 N \\
I T\end{array}$ & $\begin{array}{l}43 \\
7 G\end{array}$ & $\begin{array}{l}54 \\
O E\end{array}$ & $\begin{array}{c}86 \\
Y\end{array}$ & $\begin{array}{c}10 \\
42 \\
D\end{array}$ & \\
\hline I. & $3 S R-5$ & A & $\mathrm{R}$ & $\mathrm{N}$ & A & $\mathrm{K}$ & $N$ & $N$ & $\mathrm{~T}$ \\
\hline 2. & 3SR-37 & $A$ & C & $\mathrm{N}$ & $A$ & $\mathrm{~K}$ & $\mathrm{~N}$ & $N$ & $\mathrm{~T}$ \\
\hline 3. & $3 S R-47$ & $A$ & C & $\mathrm{N}$ & $A$ & $\mathrm{~K}$ & $\mathrm{~N}$ & $\mathrm{~N}$ & $\mathrm{~T}$ \\
\hline 4. & $3 S R-54$ & - & - & - & $A$ & $\mathrm{~K}$ & $\mathrm{~N}$ & $N$ & $\mathrm{~T}$ \\
\hline 5. & 3SR-84 & $A$ & $\mathrm{R}$ & $\mathrm{N}$ & $A$ & $\mathrm{~K}$ & $Y$ & $\mathrm{~N}$ & $\mathrm{~T}$ \\
\hline 6. & $3 S R-86$ & $A$ & $\mathrm{R}$ & $\mathrm{N}$ & A & $\mathrm{K}$ & $\mathrm{N}$ & $N$ & $\mathrm{~T}$ \\
\hline 7. & $3 S R-87$ & - & - & - & - & - & $N$ & $N$ & $\mathrm{~T}$ \\
\hline 8. & 3SR-98 & - & - & - & $A$ & $\mathrm{~K}$ & $Y$ & $\mathrm{~N}$ & $\mathrm{~T}$ \\
\hline 9. & $3 S R-121$ & - & $\mathrm{R}$ & - & $A$ & $\mathrm{~K}$ & $\mathrm{~N}$ & $\mathrm{~N}$ & $\mathrm{~T}$ \\
\hline 10. & 3SR-I45 & $A$ & C & $\mathrm{N}$ & $A$ & $\mathrm{~K}$ & $Y$ & $\mathrm{~N}$ & $\mathrm{~T}$ \\
\hline 11. & $3 S R-147$ & A & $C$ & $N$ & A & $\mathrm{K}$ & $Y$ & $N$ & $\mathrm{~T}$ \\
\hline 12. & $3 S R-164$ & $A$ & $C / R$ & $\mathrm{~N}$ & A & $\mathrm{K}$ & $Y$ & $N$ & $\mathrm{~T}$ \\
\hline 13. & $3 S R-168$ & - & - & - & $A$ & $\mathrm{~K}$ & $Y$ & $N$ & $\mathrm{~T}$ \\
\hline 14. & $3 S R-213$ & A & $\mathrm{C}$ & $S$ & $A$ & $\mathrm{~K}$ & $\mathrm{~N}$ & $N$ & $\mathrm{~T}$ \\
\hline 15. & $3 S R-223$ & - & - & - & $A$ & $\mathrm{~K}$ & $Y$ & $N$ & $\mathrm{~T}$ \\
\hline 16. & $3 L W-32$ & A & C & $S$ & - & - & $\mathrm{N}$ & $N$ & $\mathrm{~T}$ \\
\hline 17. & $3 L W-94$ & - & $\mathrm{R}$ & - & A & $\mathrm{K}$ & $Y$ & $N$ & $\mathrm{~T}$ \\
\hline 18. & $3 L W-101$ & - & - & - & $A$ & $\mathrm{~K}$ & $Y$ & $N$ & $\mathrm{~T}$ \\
\hline 19. & $3 L W-103$ & - & C & - & - & - & $\mathrm{N}$ & $N$ & $\mathrm{~T}$ \\
\hline 20. & $3 L W-107$ & - & - & - & $A$ & $\mathrm{~K}$ & $Y$ & $N$ & $\mathrm{~T}$ \\
\hline 21. & $3 L W-147$ & - & - & - & - & - & $\mathrm{N}$ & $N$ & $\mathrm{~T}$ \\
\hline 22. & $3 L W-187$ & $A$ & $C / R$ & $\mathrm{~N}$ & $A$ & $\mathrm{~K}$ & $\mathrm{~N}$ & $\mathrm{~N}$ & $\mathrm{~T}$ \\
\hline 23. & $3 L W-197$ & - & - & - & - & - & $N$ & $N$ & $\mathrm{~T}$ \\
\hline 24. & $3 L W-202$ & - & - & - & $A$ & $\mathrm{~K}$ & $\mathrm{~N}$ & $N$ & $\mathrm{~T}$ \\
\hline 25. & 3LW-203 & $A$ & C & $\mathrm{N}$ & $A$ & $\mathrm{~K}$ & $\mathrm{~N}$ & $N$ & $\mathrm{~T}$ \\
\hline 26. & $3 L W-210$ & - & $\mathrm{R}$ & - & - & - & - & - & - \\
\hline
\end{tabular}

population in the eastern part of Indonesia where malaria is highly endemic $[13,14]$. Southeast Asian Ovalocytosis is a dominantly inherited haematological condition arising from the deletion of $\mathrm{Ala}^{400}-\mathrm{Ala}^{408}$ in the band 3 gene [15]. The higher frequency of SAO in the population of malaria endemic area of Southeast Asia and Melanesia supports the hypothesis that this genetic defect provides relative resistance to malaria. Subsequent studies reported that erythrocytes from SAO subjects are not resistant to invasion by $P$. falciparum but that the condition is associated with protection against severe malaria in children $[16,17]$. The mechanism(s) by which SAO confers protection to severe malaria remains unclear but some evidence indicates that it may be associated with reduced cytoadherence $[13,17]$. In this regard, it is of particular interest to explore further whether the frequency of SAO, at least among the ethnic population of Indonesia, is associated with malaria endemicity.
The results of haemoglobin measurements showed a high prevalence of anaemia among children in Nias District. However, there was no significant association between anemia and parasitemia. This finding indicates that anaemia alone cannot be used as a good predictor for malaria in this area. Other possibilities including nutritional anaemia or hookworm infection should be further explored $[18,19]$.

The results of the mosquito survey are also very similar to the previous reports that An. sundaicus was the predominant species along the coastal areas of Sumatra and Nias. Although in this survey only three anopheline species were detected, An. barbirostris that was found to breed in lowland rice field has never been reported previously [2]. The relatively few anopheline species found during the surveys is somewhat surprising as the three surveys were conducted during the rainy season. The finding may either be associated to the relatively heavier rainfall during the survey period that flushed away most of the breeding sites or it is probably biased by the limitations in sampling time and location.

In conclusion, the cross-sectional surveys in three different sub-districts of Nias District clearly demonstrate the presence of relatively stable malaria endemic foci in Nias District, North Sumatra Province Indonesia. Molecular analysis of the malaria parasite isolates collected from this area strongly indicate resistance to chloroquine and a growing threat of resistance to sulphadoxine-pyrimethamine. This situation highlights the need of developing a sustainable malaria control measures through regular surveillance and proper antimalarial drug deployment.

\section{Authors' contributions}

DS designed the study and was responsible for data collection, management, fund raising for this study and the manuscript writing. PBSA performed the molecular analysis, data analysis, and also was involved in manuscript preparation. IW, RMD, ST, IL, WH and PZ collected field samples and performed data analysis. FL and AHS contributed to the experimental design, data analysis and the manuscript writing. All authors read and approved the manuscript.

\section{Acknowledgements}

The authors wish to thank health professional staff at the Puskesmas Lahewa, Sirombu and Mandrehe of Nias District for their assistance during the surveys, Dr. W. Rogers of the US-NAMRU-2, Jakarta for critical reading of the manuscript, Prof. S. Marzuki of the Eijkman Institute for Molecular Biology for his encouragement and support, Dr. Steven Bjorge of the WHO office in Jakarta for his advice, and BSc (Hons) students Rodiah Nababan and Muhamad Ridwan for their technical assistance in genetic analysis. This study received financial support from WHO/APW INO EHA 050.XD.04.D.-Sticker No. SE/05/427I 26. 


\section{References}

I. Baird JK, Sustriayu NMF, Basri H, Masbar S, Leksana B, Tjitra E, Dewi RM, Hairani , Wignal FS: Survey of resistance to chloroquine by Plasmodium vivax in Indonesia. Trans R Soc Trop Med Hyg 1996, 90:409-4II.

2. Fryauff DJ, Leksana B, Masbar S, Wiady I, Sismadi P, Susanti Al, Nagesha HS, Syafruddin , Atmosoedjono S, Bangs MJ, Baird JK: The drug sensitivity and transmission dynamics of human malaria on Nias Island, North Sumatra, Indonesia. Ann Trop Med Parasitol 2002, 96:447-462.

3. Tjitra E, Gunawan S, Laihad FHM, Sulaksono S, Arjoso SLRT, Manurung N: Evaluation of antimalarial drugs in Indonesia I98I1995. Buletin Penelitian Kesehatan 1997, 25:27-58.

4. Schwartz IK, Lackritz EM, Patchen LC: Chloroquine resistant Plasmodium vivax from Indonesia. New Eng J Med I 991, 324:927.

5. Collins WE, Schwartz IK, Skinner JC, Morris C, Filipski VK: The susceptibility of the Indonesian I/CDC strain of Plasmodium vivax to chloroquine. J Parasitol 1992, 78:344-349.

6. Gamage-Mendis AC, Rajakaruna J, Weerasinghe S, Mendis C, Carter $\mathrm{R}$, Mendis KN: Infectivity of Plasmodium vivax and Plasmodium falciparum to Anopheles tesselatus; relationship between oocyt and sporozoite development. Trans R Soc Trop Med Hyg 1993, 87:3-6.

7. Imei C, Ikemoto T, Takagi M, Yamugi H, Pohan W, Hasibuan H, Sirait H, Panjaitan W: Ecological study of Anopheles sundaicus larvae in a costal village of north Sumatra, Indonesia, I Topography, land use and larva I breeding. J Sanitation and Zoology (Japan) 1998, 39:293-300.

8. World Health Organization: Weekly epidemiological record. 2005, 80: 157-164.

9. Wooden J, Kyes S, Sibley CH: PCR and strain identification in Plasmodium falciparum. Parasitol Today 1993, 9:303-305.

10. Syafruddin D, Asih PBS, Casey G, Maquire J, Baird JK, Nagesha HS, Cowman AF, Reeder JC: Molecular epidemiology of Plasmodium falciparum resistance to antimalarial drugs in Indonesia. Am J Trop Med Hyg 2005, 72:I74-I8I.

I I. Baird JK: Chloroquine resistance in Plasmodium vivax. Antimicrob Agents Chemother 2004, 48:4075-4083.

12. Wang P, Read M, Sims PF, Hyde JE: Sulfadoxine resistance in the human malaria parasite Plasmodium falciparum is determined by mutations in dihydropteroate synthase and an additional factor associated with folate utilization. Mol Microbiol 1997, 23:979-986.

13. Kimura M, Soemantri A, Ishida T: Malaria species and Southeast Asian Ovalocytosis defined by a 27-bp deletion in the erythrocyte band 3 gene. Southeast Asian J Trop Med Public Health 2002, 33:4-6.

14. Syafruddin D, Asih PBS, Coutrier FN, Trianty L, Noviyanti R, Luase Y, Sumarto W, Caley M, van der Ven AJAM, Sauerwein RW: Malaria in wanokaka and loli sub-districts, West Sumba district, East Nusa Tenggara Province, Indonesia. Am J Trop Med Hyg 2006, 74:733-737.

15. Jarolim P, Palek J, Amato D, Hassan K, Sapak P, Nurse GT, Rubin HL, Zhai S, Sahr KE, Liu SC: Deletion in erythrocyte Band 3 gene in malaria-resistant Southeast Asian Ovalocytosis. Proc Natl Acad Sci USA 1991, 88: I 1022-I1026.

16. Allen SJ, O'Donnel A, Alexander ND, Peto TEA, Clegg JB, Alpers MP, Weatherall DJ: Prevention of cerebral malaria in children in Papua New Guinea by SoutheastAsian ovalocytosis. Am J Trop Med Hyg 1999, 60:1056-1060.

17. Kimura M, Soemantri A, Siswanto JE, Ishida T: Ovalocytosis without band 3 gene 27-bp deletion and malaria infection. Anthrop Sci 2006, I |4: I6I-164.

18. Margono SS: Review on the control of soil-transmitted helminthiases in Indonesia: the role of parasitologists. Collected Papers on the Control of Soil-transmitted Helminthiases 2001:I69-I72.

19. World Health Organization: Communicable disease profile for tsunami affected areas of Indonesia. Communicable disease team, WHO/ACEH Indonesia 2005: I 33 [http://www.who.int].
Publish with BioMed Central and every scientist can read your work free of charge

"BioMed Central will be the most significant development for disseminating the results of biomedical research in our lifetime. "

Sir Paul Nurse, Cancer Research UK

Your research papers will be:

- available free of charge to the entire biomedical community

- peer reviewed and published immediately upon acceptance

- cited in PubMed and archived on PubMed Central

- yours - you keep the copyright

Submit your manuscript here:

http://www.biomedcentral.com/info/publishing_adv.asp
BioMedcentral 